\title{
Hvad kunde Grundtvig i dag betyde for reformerte kristne?
}

\author{
Af G.F.W. Herngreen \\ (Forkortet gengivelse)
}

\begin{abstract}
Foranstående artikel er skrevet på tysk på opfordring af GrundtvigStudiers redaktion. Forfatteren er reformert teolog og forhenværende præst i Haag, taler og læser dansk og har flere gange besøgt Danmark, i 1975 med understøttelse af udenrigsministeriet på GrundtvigSelskabets anbefaling. Han har skrevet om Grundtvig på hollandsk og holdt to radioforedrag om ham, der er trykt i det teologiske tidsskrift Rondom het Woord november 1975 (17. årgang nr. 4). -
\end{abstract}

Grundtvig har indtil for kort tid siden været næsten helt ubekendt i nederlandsk kirke og teologi. Kun i folkehøjskolekredse har man kendt til ham og hans opdragelsestanker, dog uden megen forståelse for den hele Grundtvig og for sammenhængen mellem hans skoletanker og hans folkelige og i særdeleshed kirkelige grundtanker.

Da man især er stødt på Grundtvigs navn ved læsningen af Søren Kierkegaard og hans tilintetgørende dom over Grundtvig, er han $\mathrm{i}$ de fleste tilfælde blevet skudt til side allerede før han havde kunnet komme til orde. Han bliver end ikke nævnt i nogen dogmatik. Hans "mageløse opdagelse“ er aldrig kommet til at anfægte nogen hollandsk bibelfortolker. Vel bliver han nævnt i kirkehistoriske håndbøger, men $\mathrm{i}$ den tyske „Heussi“ stod før 2. verdenskrig den groteske påstand, at Grundtvigs teologiske hovedpåstand (fra 1825) skyldtes hans tyskerhad (efter krigen 1848-49). Også Karl Barth nævner ham kun en enkelt gang, og da blot som det 19. århundredes tydeligste virkelige forløber for den moderne folke- og skabelsesordningsteologi. Det ser ud, som om Barth har sin viden fra de tyske oversættelser af H. L. Martensen (Social Ethik 1888) og N. H. Søe (Kristelig Etik). Og dog havde han haft lejlighed til at læse Regin Prenters artikel i den samling, 
der i 1936 blev tilegnet Barth („Die Frage nach einer theologischen Grundtviginterpretation"). Det vilde bestemt have været interessant og frugtbart, om Barth havde kendt Grundtvigs virkelige tanker og udførligt taget stilling til dem. De tos lære om det levende, skabende Gudsord er - trods alle de forskelle, der sikkert findes her - både hos Grundtvig og Barth ikke den hellige Skrift, men den levende Herre selv. Heri lå der og ligger der stadig økumeniske muligheder. Her skal blot nævnes Barths lære om Guds gode skaberværk.

Dersom man i Holland overhovedet kunde forestille sig noget ved navnet "Grundtvig", var det billedet af en romantisk, patriotisk, nationaltkristelig, folkekirkelig dansker; og eftersom også Holland kun alt for godt har kendt den nære forbindelse af nationalt og kristeligt og den kritiske teologi så sig alvorligt nødsaget til at løsne de nære forbindelser og identifikationer, som her gik lige lukt ind i det politiske, havde man bestemt ikke brug for en sådan Grundtvig. I bedste fald så man ham som en vækkelsesfigur, der havde kæmpet mod rationalismen, men den slags har man også i Holland haft nok af!

Hvor karakteristiske Grundtvigs tanker end kan være, tilhører han $\mathrm{i}$ det store og hele den lutherske tradition, og det er måske til dels kun ud fra lutherske forudsætninger, man helt kan gøre hans stillingtagen forstålig. I hvert fald er det uomgængeligt at bortrydde nogle dybt rodfæstede misforståelser på begge sider, før et virkeligt møde kan komme i stand. Efter min mening frembyder netop Grundtvig her - trods hans skarpe værgen sig mod en forøvrigt delvis falsk opfattet kalvinisme - originale muligheder!

Da jeg som student i 1936 tilbragte en uge i Askov og udtalte den mening, at Grundtvig også kunde frugtbargøres uden for Danmark, fx. i Holland, forsikrede man mig, at "grundtvigianisme ikke var nogen eksportartikel“. Var dét rigtigt, så havde Grundtvigs tanker uden videre mistet deres værdi. En lære, der fremstiller sig som væsentlig kristen, kan netop af den grund ikke forblive begrænset til ét folk. Så vilde det ikke være nogen kristen lære, men et nationalistisk kætteri. Jeg lod mig derfor ikke afskrække, men belære (bl. a. ved læsning af Anders Nørgaards skrifter) og har altid troet, at Grundtvig havde noget væsentligt at sige den hele kristenhed, de reformerte iberegnet, i alle lande. Og hans overmåde 
rige salmedigtning må også frugtbargøres i kirkerne uden for Danmark.

At dette er muligt (trods de vanskeligheder, der er nævnt af Uffe Hansen i Grundtvig-Studier 1975 s. 68) har vist sig klart i Holland. Netop i skikkelse af den store salmist er han nu endelig indtrådt $\mathrm{i}$ det nederlandske kirkeliv. Fem salmer er allerede $\mathrm{i}$ begyndelsen af 1960-erne blevet oversat til hollandsk af Muus Jacobse (professor K. Heeroma) med bevarelse af den oprindelige rytme og den danske melodi. Tre af disse blev foreslået til optagelse i den nye hollandske "Liedboek“ (salmebog): Herren han har besøgt sit Folk, Vor Herre, til dig må jeg ty og Kirken den er et gammelt Hus (en særlig god oversættelse, der ubegribeligt nok ikke blev optaget), og der er planer om at oversætte flere Grundtvigsalmer i de kommende år. Salmebogen benyttes af de fem vigtigste kirker i Holland: den nederlandske reformerte, de (frie) reformerte kirker i Nederlandene, den evangelisk-lutherske kirke, „mennoniterne“ (Die Taufgesinnte Societät) og den remonstrantisk reformerte kirke, som opstod i 1618-19 som protest mod den dengang så hårde forudbestemmelseslære). Optagelsen af to salmer af Grundtvig gav anledning til nogle artikler om den teologiske baggrund for disse salmer. $\mathrm{Og}$ således får overskriftens „idag“ en mening: der findes grundlag, omend meget begrænset, for en Grundtvigdiskussion i det reformerte Holland.

Det første tema, der var at omtale, gjaldt Grundtvigs tale om Guds levende Ord i forhold til Den hellige Skrift. Hvad Grundtvig har at sige, i opposition mod det vanlige protestantiske skriftprincip, rammer hele protestantismen, lutheraner og reformerte, rationalister (som i 1825) og en bibelortodoksi som den, der rykkede frem efter 1860. At „døde bogstaver intet formår" - kærnepunktet i Grundtvigs teologi - fremkalder utallige problemer vedrørende autenticitet og udlægning. Det udleverer os en papirpave, omgivet af mange prælater, af hvem jævne medlemmer af menigheden bliver afhængige for deres sjæl og saglighed i liv og død -om de da ikke, som vi nutildags mer og mer oplever, gør sig selv til prælater eller endog bliver hver sin egen pave.

Grundtvig har rigtigt forstået, hvad Karl Barth senere formulerede således: at ortodoksi og rationalisme er „børn af den samme svage ånd". Ordet er blevet kød, ikke skrift. Linien fører ikke fra Gud og Kristus via Skriften til Kirken eller måske endog direkte 
til den Enkelte. Menigheden var der fra første begyndelse af med Herren selv i sin midte, "lyslevende til stede“. Dér blev ikke talt om ham, dér talte han selv i ord, som er ånd og liv, ved dåb og nadver, længe før blot et bogstav af Det nye Testamente var nedskrevet. Kirken hviler ikke på Skriften, men Den hellige Skrift vokser i Kirken. Den har sin traditionshistorie, vilde vi i dag sige; den er vidnesbyrdet om troen og den levende Kirkes lære, dens undervisningsbog.

Det gælder, ikke mindst i reformerte kredse, om at tydeliggøre, at denne "historisk-kirkelige anskuelse" på ingen måde fratager Bibelen dens værd. Bibelen er enestående. Men troen skænker den ikke: det gør kun den levende Herre selv gennem hans Ånd i det levende Ord, som lyder i menigheden. Herren skriver ikke til os, han taler os til. Atter og atter peger Grundtvig på de gamle bibelsteder, som forudsætter et levende, mundtligt Ord af Herren i menigheden. Bibelen fortolker det, kalder os til at leve ud af dette Herrens Ord, men den ER ikke dette Ord selv. Om Grundtvigs almindelige syn på forholdet mellem skrevet og talt ord her spiller en primær rolle, kan her forblive uafgjort. Hans omgang med myte og sagn har i hvert fald styrket ham i den overbevisning, at ord ikke er formler for begreber; sprog er ikke semantik, men poëtik; det fremkalder virkeligheder og taler fra hjerte til hjerte. Den digtende, syngende „Skjald“ står ham for øje, i levende vekselvirkning med hans tilhørerskare.

Men den dybeste grund til Grundtvigs søgen efter et direkte ord af Herren selv ligger efter min mening $i$ nærheden af Luthers spørgsmål: „Hvordan får jeg en nådig Gud?" Enhver, der i Skriften søger efter at blive tiltalt personligt, kan let komme i forvirring: Hvad er bestemt for mig? og: Hvad betyder det? Dermed falder man atter i papirpavens prælaters hænder. Men Herrens eget levende „Mundsord“ mødte Grundtvig i dåb- og nadverliturgiens lapidare sætninger: „Tror Du ...? Jeg døber Dig ... Fader Vor ... Tag, spis, drik ... Fred være med Jer!" Grundtvig oplever det som en overvældende befrielse, der behersker tonen $i$ hans salmer et langt stykke vej. For ham handlede det om Den gode Hyrde selv, der kaldte sine får ved navn, hvert med dets eget, personligt. Derfor de ord, der måske er sat på spidsen og ofte er blevet bestridt: „Kun ved Badet og ved Bordet hører vi Guds Ord til os" - til os personligt, "Ordet, der skaber hvad det nævner", og 
som ikke først skulde blive Skrift, men fra begyndelsen af gennem århundrederne bliver overleveret levende talt i menigheden. Man har ofte overset denne eksistentielle karakter af den grundtvigske tese. $\mathrm{Og}$ dog klinger den os i møde fra alle hans salmer, så den ikke er til at overhøre.

Denne koncentration om de sakramentale ord som egentligt Gudsord er problematisk for den reformerte ortodoksi, men ikke mere problematisk end for den lutherske. Ja, der findes også i den reformerte protestantisme tilknytningspunkter, som muliggør en forståelse for Grundtvigs dybeste anliggende. Det kunde forekomme lutheranerne underligt, ikke mindst grundtvigianerne, som har læst Grundtvigs skarpe nedvurdering af den reformerte nadverlære, oven i købet endnu i Grundtvig-Studier 1975 (s. 15). Men netop her råder der hårdnakkede misforståelser med hensyn til den reformerte nadverlære, som endelig engang må ryddes af vejen.

Grundtvig var, som såmange lutheranere, af den mening, at de reformerte med deres "significat" (brød betyder Kristi legeme, henviser kun, er "kun“ tegn) i stedet for "est" (brød bliver legeme, eller „i, med og under" brød er Kristi legeme) gjorde et udsagn, hvori de nægtede Kristi virkelige nærværelse i sakramentet, og reducerede hele nadverbegivenheden til en erindringshøjtidelighed uden nærværelse, i hvilken troen retter sig imod det forgangne og drager sig opad derved, uden at der sker noget virkeligt fra Guds side.

Det er på tide at skyde denne misforståelse til side for bestandig. Hvor mange forskelle der end er mellem luthersk og kalvinsk nadverlære, så véd også den kalvinske lære, at det i sakramentet drejer sig om en handlen af Gud, om virkelighed, frelsende nærværelse af Jesus Kristus selv. Også Grundtvig tager „significat“ i brug, når han taler om elementerne brød og vin (se atter Chr. Thodbergs bidrag til Grundtvig-Studier 1975). Kristi legemlige, fuldt-personlige nærværelse finder han i nadverordet: det er Den gode Hyrdes tiltale til sin hjord og i denne til hvert medlem personlig, en tiltale, hvori Han er nærværende "lyslevende“. Vi kan måske udtrykke det således: det materielle, det at tage, føle, spise, smage i hele dets sanselighed, denne legemlige begivenhed besegler sandheden af denne personlige præsens (nærværelse) og er lige så uundværlig som faderens omfavnelse og kys i lignelsen om den 
fortabte søn (Luk 15) ved siden af de afgørende ORD: „Denne min søn!" Hvis der kun var ord, vilde resultatet blive en distanceret platonisme. Netop omfavnelsen og kysset er udtryk for en total tilgivende kærlighed, der omfatter den fortabte søn i hele hans konkrete eksistens.

Kalvinisterne har med deres „significat", ligesom Grundtvig, aldrig villet benægte den virksomme nærværelse af den hele Kristus i nadveren. De føler sig derfor heller ikke ramt af Grundtvigs kritik i denne henseende.

I almindelighed ligger forskellen i akcent mellem luthersk og kalvinsk lære snarere deri, at hos Luther var spørgsmålet om frelsesvisheden det centrale, mens det for Calvin var Guds suverænitet, der stod i centrum. Derfor vogter den rigtige kalvinske teologi sig altid for ethvert udsagn, der kunde give det indtryk, at vi mennesker kunde disponere over Gud, over hans nærværelse - fx. i den romerske messe over konsekration og efterfølgende transsubstantiation. - Dersom Herren er med os, hos os, så er han det i sin egen suveræne frihed, når og hvor det behager Ham. Det lod sig bedst sige med de ord: „Per Spiritum sanctum“ - gennem den Hellige Ånd, - som modus for Kristi nærværelse. "Ånd" betyder Guds suveræne, frie virksomhed og er uløselig forbundet med Guds ord. „Ånd" betyder altså ingen spiritualisering, åndeliggørelse, luftiggørelse af den konkrete virkelighed, uvirkeliggørelse eller endog fuldkommen subjektivering. „Per Spiritum Sanctum“ vil sige: i kraft af Hans frie, suveræne virken er den hele Kristus, den kødblevne, korsfæstede og opstandne selv til stede fuldtud personlig. Se herom også den udmærkede oversigt, som Yngve Brilioth har givet over "den reformerta linjen“ $i$ hans "Nattvarden $i$ evangelisk Gudstjänstliv“, spec. under III: „Den calvinska nattvardsuppfattningen“ (s. 233-241) og under V - „De anglosaxiska samfunden" - om den skotske teologi (s. 263-275).

Dette eftertryk på den guddommelige virksomheds suveræne frihed berøver os imidlertid, anderledes end man måske kunde tænke sig, den frelsesvished, som førte Luther til hans lidenskabelige brug af „EST" i hans nadverlære, og som var så vigtig for Grundtvig, omendskønt han (på god kalvinsk måde!) flyttede akcenten fra de i sig selv uundværlige elementer til nadverordene. Vel fratager Calvins lære os enhver mulighed for fra vor side at garantere Kristi nærværelse - Gud er den frie - men Guds frihed er aldrig 
vilkårlighed, den ophæver ikke Hans trofasthed: Han holder hvad Han i troskab har lovet os. Derfor kender også kalvinisten til frelsesvisheden, som netop er givet i sakramentet, at tilgivelse og evigt liv er beskåret „ikke blot andre men også mig“. Også i kalvinismen er Den gode Hyrdes helt personlige stemme i sakramentet at høre.

For en udførlig analyse af denne tanke vilde jeg gerne nævne den efter min mening bedste, smukkeste, dybsindigste og med den fra reformert side dybeste, med inderlig deltagelse og kærlighed skrevne afhandling: „Ansatz und Absicht in Luthers Abendmahlslehre“. Den står i „Die Theologie und die Kirche“, Gesammelte Vorträge Band 2, 1928; forfatteren er Karl Barth.

For at sammenfatte: den reformerte nadverlære giver betydningsfulde muligheder for en forståelse af Grundtvigs dybeste anliggende: Hvor hører vi Guds ord til os, personligt. Også Calvin vilde hver søndag have holdt nadver, dersom byen Geneves råd ikke havde forhindret ham deri med et forbud. Og i dag findes der i den reformerte kirke et tiltagende antal menigheder, der holder nadver meget oftere end én gang i løbet af de traditionelle tre måneder. Dertil kommer, at den af Chr. Thodberg i hans ovenfor omtalte artikel nævnte indsnævring til en næsten exclusiv langfredagsstemning også her bliver mer og mer overvundet og de af Thodberg nævnte momenter: fællesskab, vertikalt og horisontalt, lovsang og eskatologisk perspektiv bliver indsat i deres gyldighed.

$\mathrm{Vi}$ vender nu tilbage til hovedlinien i denne artikel. Miskendelsen af Grundtvigs dybeste anliggende ses tydeligt i den måde, hvorpå man - hvis man overhovedet kender noget til ham - hos os gennemgående vurderer den brug, Grundtvig gør af den apostolske trosbekendelse (Apostolikum). Selv er han ikke ganske uden skyld deri. Idet han følger Irenæus, opdager han den som „Sandhedens Rettesnor“. I „Kirkens Gienmæle“ og også senere fungerer den som norm for svaret på, hvem der kan høre til kirken. Denne brug førte til forvirring, især da en af hans tilhængere yderligere uddybede den gamle legende om en mundtlig overlevering af Apostolikum fra Jesus selv til apostlene. Her er det punkt, på hvilket $\mathrm{S}$. Kierkegaard kunde angribe Grundtvig: selv det historiske faktum giver ikke det al usikkerhed udelukkende faste punkt. Tro er aldrig „objektiv“, men altid et spring, og al historisk vished er altid approximativ, altid vished indtil videre! Men Kierkegaard har ikke forstået, at denne teori om Apostolikum kun var en sekundær ratio- 
nalisering af en primær erfaring, en oplevelse, en viden sig direkte tiltalt.

Dette fremgår af et sted i Den christelige Børne-Lærdom i kapitlet „Det evige Livs-Ord af Vorherres egen Mund til Menigheden (Værker i Udvalg VI s. 239), hvor Grundtvig siger, at han ved trosbekendelsen forstår „Menighedens eget lydelige Ja og Amen og ikke ... nogle gamle Opskrifter af det saakaldte Symbolum Apostolicum ..." Apostolikum indeholder ingen dogmer, men fortæller hvem Gud er i det, han gjorde, gør og vil gøre som Fader, Søn og Aand.

At Apostolikum i Danmark ved dåben netop ikke bliver udtalt af menigheden, men i spørgeform rettet til dåbsbarnet, er for reformerte, der altid stiller dåbsspørgsmålene til forældrene, vanskeligt at forstå; men måske er det til at tydeliggøre for dem, at netop denne form af spørgsmålet for Grundtvig var væsentlig: den betyder, at Herren selv ganske personligt siger til dette nye medlem af sin menighed, hvem Han vil være for det, før det kan bringe Ham blot det ringeste til svar - derfor svarer fadderne i dets sted at Han kærlig indbyder det til at modtage Ham som Han er. Altså ingen forelæsning af koncentreret dogmatik, ingen eksamen i rettroenhed, men levende tilbud af en gave, som er Ham selv.

Derfor er den sædvanlige dom, at Grundtvig havde stillet Apostolikum i Bibelens sted, fuldstændig falsk. Han gjorde noget ganske andet. Han brød med en anskuelse af ORDET, der - ortodokst eller rationalistisk - opfattede Ordet som meddelelse af data og sandheder, og satte i dens sted ORDET som personligt, skabende kald. Dette Ord, og deri Herren selv, fandt han derpå i den levende, bekendende menighed, ved dåben i trosordet (Apostolikum) og dåbsordet, og derpå i Fadervor, som et menneske, der ved dåben er blevet Guds barn, får lagt på læberne som håbets ord; og derpå kommer nadveren med kærlighedens ord, som er det største af dem alle, og endelig sammenfatter "Fred" det hele som Hans egen hilsen. Sammen står det meget smukt i den desværre endnu ikke optagne salme Kirken den er et gammelt Hus med dens „Fred være med Eder alle," til slut.

Men betyder det ikke en tilbagevenden til det romerske traditionsbegreb? Aldeles ikke. Vel kunde man sige med Anders Nørgaard, at Grundtvig søgte en vej tilbage bagom både katolicisme og protestantisme. Men Grundtvig kender intet efterhånden vok- 
sende "depositum fidei“ så lidt som et ufejlbart læreembede. Læren tilhører skolen, og der skal der herske frihed. Og vilde man alligevel tale om tradition, så vilde det kun dreje sig om en "traditio pastoralis“, at Den gode Hyrdes stemme fortsat bliver ved med at lyde.

Grundtvig syn har, som jeg mener, endnu stadig sin betydning for den økumeniske samtale, også med reformerte, der i Nederlandene mange gange står i kontakt med romersk-katolske samtalepartnere. Grundtvig giver forholdet mellem skrift og tradition en speciel akcent. Han modsætter sig en steril rationalisme såvel som en død bogstavortodoksi. Han ser Guds frelseshandlen som talende virkelighed. Han har brudt med al høj- og statskirkelig institutionalisme, men fortaber sig ikke $\mathrm{i}$ en menighedsteologisk sump, hvor alting drejer sig om vor fromme eller aktivistiske forbundethed. Han forkaster den pietistiske individualisme og tager som udgangspunkt for sin tænkning Kristi nærværelse i menigheden som et hele, men ikke for dens egen fromme erfarings skyld. Den personlige oplevelse får inden for disse sammenhænge atter sin ret.

Reformerte kristne har altid lagt vægt på, at den rette liturgi finder sted i det verdslige, daglige liv. Den vægt, Grundtvig lægger på Herrens „mundsord“ ved dåb og nadver synes at føre til et fra verden bortvendt kultfællesskab. Det er vigtigt at gøre det ganske tydeligt, at Grundtvigs kristne tænkning ikke isolerer ham fra det jordiske, konkret-menneskelige liv, men netop fører ham til den inderligste deltagelse deri. Den Herre, vi møder med bøn, bekendelse og loviang i gudstjenesten, er Forløseren - ikke fra det brogede liv derude, nej, Han forløser netop dette af Ham skabte liv selv. Her er der vigtige tilknytningspunkter for reformerte kristne, som er vant til at bebrejde lutherdommen en skarp adskillelse af kirke og verden, men der er tillige ansatser til selvkritik, netop fordi Grundtvig imødegår de kalvinistiske løsninger af problemet kirkens forhold til verden med sit „Menneske først og Christen saa" og dermed går sin egen vej.

Men også her foreligger der en vigtig forskel mellem reformert og luthersk tænkning, spørgsmål, som gælder forholdet mellem lov og evangelium. Det vilde imidlertid føre for vidt denne gang at gennemgå disse spørgsmål, og således betragte Grundtvigs anden hovedtesis fra reformert synspunkt. 